удк 336.71

\title{
ЗВІТ ПРО УПРАВЛІННЯ БАНКУ ЯК ІНСТРУМЕНТ ДЕТІНІЗАЦІї ЕКОНОМІКИ УКРАЇНИ ${ }^{1}$
}

\section{BANK MANAGEMENT REPORT AS A TOOL OF DETINIZATION UKRAINIAN ECONOMY}

\author{
Савченко Тарас Григорович \\ доктор економічних наук, профресор, \\ Сумський державний університет \\ ORCID: https://orcid.org/0000-0002-5001-609X \\ Ярошина Аліна Павлівна \\ аспірант, \\ Сумський державний університет \\ ORCID: https://orcid.org/0000-0002-8694-4592 \\ Касяненко Олександр Васильович \\ аспірант, \\ Сумський державний університет \\ ORCID: https://orcid.org/0000-0002-7347-6347

\section{Savchenko Taras, Yaroshyna Alina, Kasianenko Oleksandr \\ Sumy State University}

Стаття присвячена актуальним проблемам детінізації економіки, через запровадження нової форми річної звітності - Звіту про управління. Проведено аналіз нормативно-законодавчої бази, яка регулює процес подання Звіту про управління банків, зокрема, аналізуються підходи до фрормування аудиторського висновку за даним звітом. Досліджуються напрямки систематизації інформації та ії зміст, а також проаналізовано мінімальні вимоги щодо розкриття даних у звіті. Проведено порівняльний аналіз звітів 15 українських банків за 2018-2019 рр. за допомогою бальної оцінки їх транспарентності. Проведено аналіз рентабельності активів банків з державною, приватною фрормою власності та з іноземним капіталом. Перевірено гіпотезу щодо існування прямої залежності між рівнем транспарентності та рентабельності банку.

Ключові слова: фрінансові посередники, детінізація економіки, звіт про управління, управлінський облік, рентабельність активів банку, транспарентність.

Статья посвящена актуальным проблемам детенизации экономики, через внедрение новой фрормы годовой отчетности - Отчета об управлении. Проведен анализ нормативно-законодательной базы, регулирующей процесс представления Отчета об управлении банков, в частности, анализируются подходы к формированию аудиторского заключения по данному отчету. Исследуются направления систематизации информации и ее содержание, а также проанализированы минимальные требования по раскрытию данных в отчете. Проведен сравнительный анализ отчетов 15 украинских банков за 2018-2019 гг. с помощью балльной оценки их транспарентности. Проведен анализ рентабельности активов банков с государственной, частной фрормой собственности и с иностранным капиталом. Проверено гипотезу о существовании прямой зависимости между уровнем транспарентности и рентабельности банка.

Ключевые слова: фринансовые посредники, детенизация экономики, отчет об управлении, управленческий учет, рентабельность активов банка, транспарентность.

De-shadowing of the economy is one of the highest priorities of public policy, banks, as the largest group of financial intermediaries, are one of the tools to reduce the level of shadow transactions. The European integration vector of development determines the involvement of Ukraine in the implementation of initiatives on sustainable de-

${ }^{1}$ Дослідження виконане у рамках держбюджетної науково-дослідної роботи № $0120 U 100473$ «Формування інструментарію детінізації економіки України на основі каузального моделювання траєкторій взаємодії фрінансових посередників». 
velopment. Under the Association Agreement, Ukraine should gradually approximate its own legislation to that of the EU by implementing the provisions of Directive 2013/34/EC on annual financial statements, consolidated financial statements and related reports of certain types of companies. This document focuses on the protection of shareholders, participants and third parties through the harmonization of national rules on the presentation and content of annual financial statements and management reports of certain types of limited liability companies. Submission of the Management Report helps to improve the bank's image, develop business reputation, increase customer confidence, ensure transparency and information openness of the business. The main points of the report should cover the economic, environmental, social and managerial aspects of the activity. Their disclosure by banks in the management report will ensure transparency of information on the impact of reporting financial institutions on the economy, environment and society, as well as the identification of possible risks and threats, which is important for building a sustainable state. The article is devoted to the current problems of de-shadowing of the economy through the introduction of a new form of annual reporting - the Management Report. An analysis of the regulatory framework governing the process of submitting the Report on Bank Management was conducted. The audit opinion of the Report is made. The directions of systematization of information, the maintenance are defined. The minimum requirements for the information disclosed in the structure are investigated. The purpose of the article is to analyze the Report on the management of 15 Ukrainian banks of various forms of ownership for complete disclosure and implementation of anti-corruption measures. Test the hypothesis of a link between bank transparency and profitability.

Keywords: financial intermediaries, de-shadowing of the economy, management report, management accounting, return on bank assets, transparency.

Постановка проблеми. У 2017 році були внесені зміни до Закону України «Про бухгалтерський облік та фрінансову звітність», відповідно починаючи з 2018 року великі та середні підприємства повинні разом з консолідованої фрінансовою звітністю складати і Звіт про управління. Інструкцією № 373 було визначено перелік обов'язкових структурних підрозділів, які мають бути висвітленні у Звіті, в тому числі і антикорупційні заходи (для банківського сектору). Оскільки досі немає чітко регламентованої фрорми Звіту, то фрінансові установи на власний розсуд розкривають інформацію, висвітлюючи або пропускаючи важливі аспекти. Сфрерою наших інтересів $\epsilon$ діяльність банків щодо запобігання шахрайству і зниження тіньової економіки.

Аналіз останніх досліджень і публікацій. Основна нормативна база, яка закріплює статус Звіту про управління та його структуру - це Закон України «Про бухгалтерський облік та фрінансову звітність» [1], Міжнародний стандарт аудиту № 720 [2], Порядок подання фрінансової звітності № 419 [3], Методичні рекомендації зі складання Звіту про управління № 982 [4], Інструкція про порядок складання та оприлюднення фрінансової звітності банків України № 375 [5].

Проблемі структури Звіту, висвітлення нефрінансової та фрінансової інфрормації у ньому, місця Звіту у системі управління підприємством, аналізу передумов його запровадження присвячені праці багатьох вітчизняних авторів, серед них: Безверхий К. В., Пантелєєв В. П. [6], Новіченко Л. С. [7], Царук Н. Г. [8], Савченко Т. Г., Мірошниченко О. В. [9], Шевчук В. Р., Бондар Т. А. та інші.
Виділення не вирішених раніше частин загальної проблеми. Детінізація економіки $€$ одним із вищих пріоритетів держаної політики, банки, як найбільша група фрінансових посередників виступає одним із інструментів для зниження рівня тіньових транзакцій. Проте досі недостатньо висвітлена проблема наявності механізмів ідентифікації порушень, антикорупційних заходів, які у свою чергу, мають позитивно впливати на рівень транспарентності банку.

Формулювання цілей статті (постановка завдання). Метою статті $\epsilon$ аналіз Звіту про управління 15 українських банків різних фрорм власності на предмет повноти розкриття інорормації та реалізації антикорупційних заходів. Перевірка гіпотези про зв'язок між транспарентністю банків та їх прибутковістю.

Виклад основного матеріалу дослідження. Звіт про управління $є$ досить новою фрормою звітності, що містить у собі фрінансову та нефінансову інорормацію, розкриває стан та перспективи розвитку підприємства і характеризує ключові ризики, які супроводжують діяльність [1].

Аудиторська перевірка інфрормації, наведеної в Звіті про управління $€$ важливою процедурою на виконання вимог МСА 720 «Відповідальність аудитора щодо іншої інсрормації» [2] (далі - МСА 720). Хоча, від аудитора не вимагається отримання додаткових доказів, крім тих, які отримані при перевірці фрінансової звітності, проте аудитор повинен перевірити чи не містить звіт про управління суттєвого викривлення фрінансової та нефрінансової інфрормації на основі результатів аудиту фрінансової звітності та знань, отриманих в процесі такого аудиту. 
Якщо проаналізувати положення Закону України «Про бухгалтерський облік та фрінансову звітність в Україні» [1], то можна дійти висновку, звіт про управління $€$ частиною річного звіту, та Порядком подання фрінансової звітності, затвердженим наказом Міністерства фрінансів України від 28.02.2000 № 419 [3] передбачено оприлюднення звіту про управління, фрінансової звітності та аудиторського звіту на веб-сайті суб'єкта господарювання.

При перевірці інорормації, наведеної в Звіті про управління досить складним $€$ оцінка суттєвості викривлення інформації. Пояснювальна інформація до МСА 720 надає рекомендації аудитору використати судження, що користувачами звіту про управління $€$ ті ж користувачі, що і користувачі фрінансової звітності та викривлення інфрормації в звіті про управління може вплинути на правильне розуміння фрінансової звітності.

Якщо аудитор доходить висновку, що інсрормація, відображена в Звіті про управління $€$ суттєво викривленою, аудитор повинен звернутися до управлінського персоналу, а за потреби і до тих, кого наділено найвищими повноваженнями, про внесення змін до Звіту про управління.

У випадку відмови про внесення змін до Звіту про управління аудитор повинен оцінити чи не ставиться під сумнів чесність управлінського персоналу, що може поставити під сумнів отримані аудиторські докази в процесі аудиту фрінансової звітності та необхідності надати відмову від аудиторського звіту. У інших випадках, аудитор повинен описати викривлення інсрормації а розділі «Інша інфрормація» аудиторського звіту.

На даний час немає жодного Стандарту чи Закону, який би чітко встановлював загальну форму Звіту, проте Мінфріном було прийнято Методичні рекомендації зі складання звіту про управління № 982 [4]. Рекомендовано систематизувати інформацію за такими напрямками: організаційна структура та опис діяльності підприємства; результати діяльності; ліквідність та зобов'язання; екологічні аспекти; соціальні аспекти та кадрова політика; ризики; дослідження та інновації; фрінансові інвестиції; перспективи розвитку; корпоративне управління (складають емітенти цінних паперів, цінні папери яких допущені до торгів на фрондових біржах або щодо цінних паперів яких здійснено публічну пропозицію).

Окремо для банківського сектору НБУ були внесені зміни до Інструкції про порядок складання та оприлюднення фрінансової звіт- ності банків України № 373 [5]. Було визначено, що Звіт про управління повинен розкривати фрінансову і нефрінансову інформацію, що характеризує фрінансовий стан, результати діяльності та перспективи розвитку банку, основні ризики й невизначеності, які можуть ставити під сумнів здатність продовження його діяльності.

Інструкцією визначено мінімальні вимоги щодо інорормації, яка розкривається у структурі Звіту, а саме: характер бізнесу; цілі керівництва й стратегії досягнення цих цілей; ресурси, ризики та відносини; результати діяльності та перспективи подальшого розвитку; ключові показники діяльності.

Таким чином, впровадження даної фрорми звіту повинна стимулювати банківський сектор економіки працювати прозоро, оскільки фрінансова та нефрінансова інфрормація повинна бути висвітленою.

Прототипом даної роботи є окремий розділ монографрії - «Сучасні тенденції обліку, аналізу й оподаткування в умовах євроінтеграції» [9]. У свою чергу ми пропонуємо дослідити, як змінилось розкриття інфрормації у Звітах про управління у 15 українських банках протягом 2018-2019 рр. та перевірити гіпотезу про те, що транспарентні банки $€$ більш фрінансово успішними.

Нами було проведено аналіз загальної структури Звіту, а саме включення усіх складових відповідно до Інструкції № 373. За допомогою бальної шкали ми здали оцінку про наявність та достатність розкриття інфрормації: 1 бал - повне розкриття; 0 балів - відсутність складової Звіту. Максимальний бал, при висвітленні усіх складових в повному обсязі18 балів. Аналіз проводився на основі оцінки таких структурних складових Звіту, як: характер бізнесу; зовнішнє середовище; цілі керівництва та стратегії їх досягнення; ресурси, ризики та відносини; результати діяльності та перспективи подальшого розвитку; відносини з акціонерами; пов'язаними особами та стратегічними партнерами; корпоративне управління; антикорупційні заходи; система управління ризиками.

Одним із ключових показників фрінансової успішності банку $є$ його рентабельність, тому ми консолідували результати по розкриттю інфрормації та прибутковістю для перевірки головної гіпотези (рис. 1).

Результати показують, то лідируючу позицію за рентабельністю активів посідає «Приватбанк» - він майже досягнув максимального рівня минулого року, який показав «Розра- 


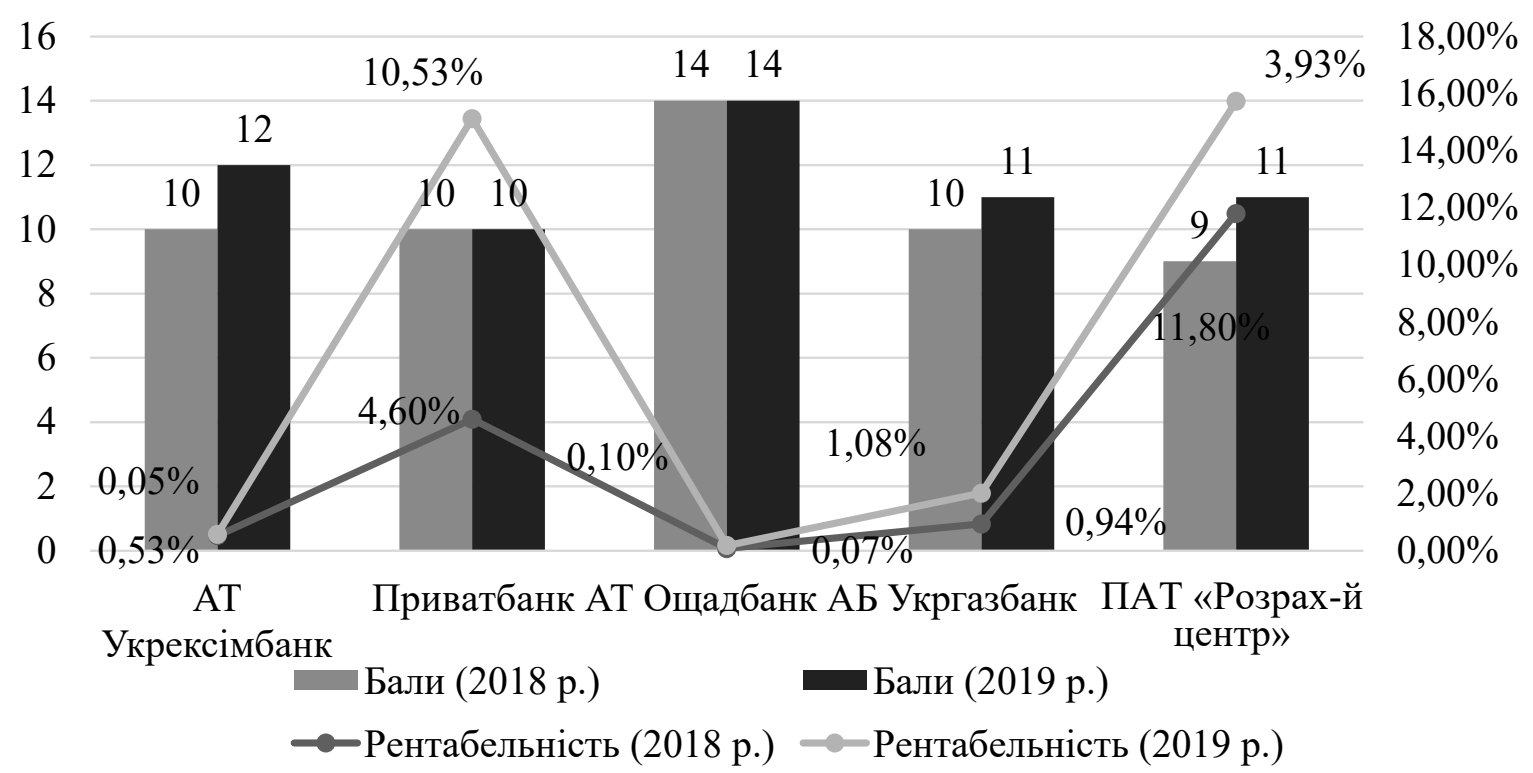

Рис. 1. Рентабельність активів банків державної власності у 2018-2019 рр., \% та бальна оцінка повноти розкриття інформації у Звіті про управління

Джерело: складено авторами

хунковий центр». Загальний рівень прибутку банку становить 32,6 млрд. грн., даний показник зріс у порівнянні з 2018 роком у 2,5 рази. Основними причинами цього $є$ : зростання бізнесу, підвищення якості кредитного портфреля, дія ринкових фракторів (динаміки валютних курсів та справедливої вартості активів банку). Позитивну тенденцію нарощування рівня прибутковості показали також «Ощадбанк» та «Укргазбанк».

Значне зниження рентабельності «Розрахункового центру» пояснюється суттєвим падінням кількості договорів щодо корпоративних цінних паперів, укладених на фондових біржах, їх кількість зменшилась у 2019 році на $67 \%$, а загальна сума договорів знизилась з 10,5 млрд. грн. до 8,25 млрд. грн.

У свою чергу «Укрексімбанк» у 2019 році отримав прибуток, який становить лише 7,5\% від показника попереднього періоду, це ж вплинуло і на загальний рівень рентабельності. Падіння було спричинене зменшенням обсягу чистого процентного доходу, зростанням операційних витрат, збільшенням витрат на формування резервів по кредитним операціям та амортизації відстроченого податкового активу.

Далі більш детальну увагу у Звітах про управляння потрібно приділити пункту, який висвітлює антикорупційну діяльність банків, що у свою чергу є важливим кроком на шляху детінізації економіки України.

Інструкцією № 373 передбачено, що банківські установи у разі, якщо середня чисель- ність їх працівників більша ніж 500 осіб, то вони зобов'язані у Звіті про управління окрім інсрормації про економічну та екологічну діяльність, соціальні аспекти висвітлити питання зайнятості, поваги до прав людини та антикорупційних заходів [3].

3 огляду на це «Розрахунковий центр», як в 2018 та і в 2019 році не розкриває інорормацію про антикорупційні заходи.

Прийнята та діє «Антикорупційна програма» у всіх інших розглянутих нами 4 державних банках, проте у Звіті «Ощадбанку» та «Укргазбанку» даний пункт $\epsilon$ більш фрормальним, тому що в ньому не висвітлені результати та ефективність даної діяльності.

В 2019 році в «Укрексімбанку» були розроблені та введені у дію внутрішньобанківські документи: «Політика запобігання конорліктам інтересів» та «Кодекс поведінки (етики).

Найбільш повно та докладно висвітлена інорормація щодо антикорупційних заходів у «Приватбанку». Працівники банку, посадові особи, керівник і засновники (учасники) у своїй внутрішній діяльності, а також у правовідносинах із діловими партнерами, органами державної влади, органами місцевого самоврядування керуються принципом "нульової толерантності" до будь-яких проявів корупції. В установі діє спеціальний канал для передачі інфрормації про фракти порушення «Антикорупційної програми».

Протягом 2019 року через наявні канали зв'язку надійшло 30 повідомлень про мож- 
ливе вчинення корупційних або пов'язаних 3 корупцією правопорушень, з них в результаті розслідування 6 повідомлень підтвердилось та щодо порушників були прийняті відповідні заходи. Банком підготовлено 185 висновків про відсутність корупційних ризиків при наданні благодійної допомоги. Антикорупційна перевірка була проведена щодо 11242 ділових партнерів банку. Якщо проаналізувати результати порівняно 22018 роком, то «Приватбанк» зробив великий крок на шляху детінізації, тому що кількість висновків щодо відсутності корупційних ризиків, які супроводжують благодійну діяльність збільшилась с 72 у 2018 р. до 185 у 2019 р. відповідно. При цьому у попередньому звітному році банк зробив 5622 перевірки ділових партнерів, що майже в 2 рази менше, ніж у 2019 році.

Суттєвих змін у структурі правління та капіталу державних банків у 2019 році в порівнянні $з$ попереднім роком не було виявлено.

Наступним кроком ми провели аналіз Звітів про управління банків, які входять до іноземних груп, таких як АТ «Райфрфайзен банк Аваль», АТ «АЛЬФА-БАНК», ОТП банк, УкрСибБанк, та АТ «Ідея Банк» (рис. 2).

Дослідивши ключові аспекти, які були висвітлені у Звітах можна дійти висновку, що в 4 із 5 банків структура Звіту фрормалізована і розкриває п'ять загальних блоків - бізнесмодель та стратегія, ринкове середовище, діяльність банку та її результати, корпоративне управління, управління ризиками. Від- значимо, що ОТП банк так, як і в 2018 році не розкриває інфрормацію, що описує бізнес-модель, ключові продукти та послуги, та стратегію управління, проте на відміну від «АЛЬФА-БАНКУ» та «дея банку» у Звіті наявні Звернення Голови Правління та Звернення Голови Наглядової ради.

3 огляду на рентабельність активів, то найбільш ефективним виявився «ддея банк», а саме: банк отримав 7,99 копійок чистого прибутку на кожну гривню використаних активів. Це пов'язане зі значним нарощуванням активів +29\% порівняно з 2018 роком. Зміна обсягів чистих активів банку обумовлена зростанням кредитного порторелю, який є основною складовою активів. Основне зростання прибутку відбулося переважно за рахунок чистого процентного доходу. Його зростання спричинене збільшенням процентних доходів завдяки значному приросту кредитного портфелю в національній валюті та виваженою політикою управління ліквідністю та вартістю залучення коштів.

Майже всі банки, окрім «Ідея банку» та «Райфрфайзен банку Аваль» у 2019 році порівняно з 2018 роком отримали вищий прибуток, проте останній все ж таки залишається лідером за обсягом прибутку. Якщо розглядати даного показника у динаміці, то прибуток «АЛЬФА-БАНКУ» зріс найбільше - на 46\% по відношенню до попереднього року.

У Звіті про управління «Райфрфайзен банк Аваль» зазначено, що вони дотримуються уні-

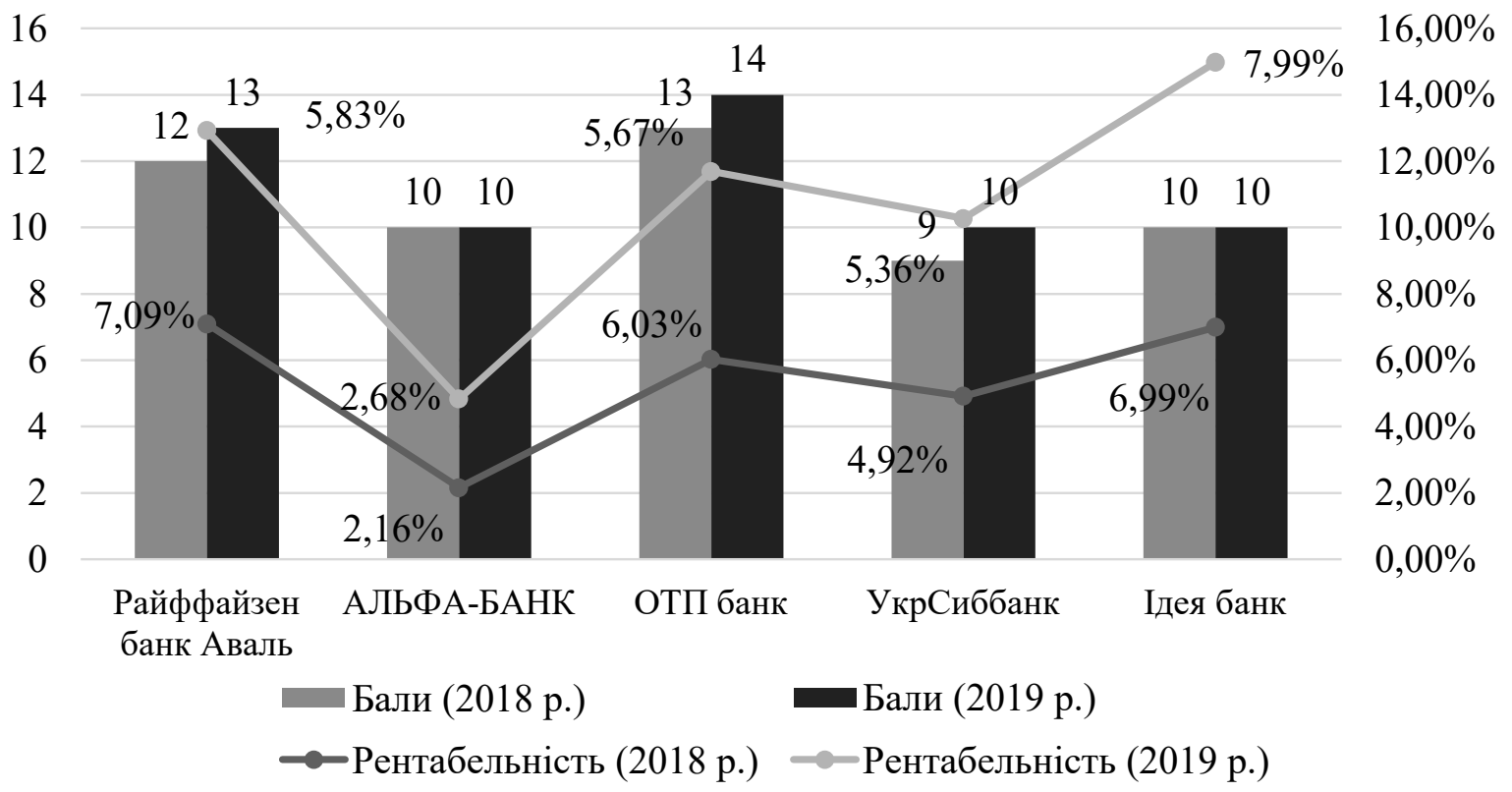

Рис. 2. Рентабельність активів банків іноземних груп у 2018-2019 рр., \% та бальна оцінка повноти розкриття інформації у Звіті про управління 
версальних принципів прав людини, охорони довкілля та боротьби з корупцією, що відповідає політиці австрійської материнської компанії Райфффайзен Банк Інтернаціональ АГ, проте більше інорормація не деталізується.

Окремого пункту про антикорупційні заходи у Звіті «АЛЬФА-БАНКУ» немає, однак варто відмітити, що на офріційному сайті у відкритому доступі $\epsilon$ «Антикорупційна програма» банку, яка містить основні антикорупційні заходи та процедури, порядок інорормування про порушення підбурювання або підозри, умови коноріденційності і захист та процедури перевірки партнерів.

Керуються принципом «нульової толерантності» до будь-яких проявів корупції та хабарництва та вживання всіх передбачених законодавством заходів щодо запобігання, виявлення та протидії корупції і пов'язаним 3 нею діям (практикам) працівники та посадові особи «ОТП банку» та «Укрсиббанку». Зокрема Відділ комплаєнсу, забезпечує розробку та вжиття заходів, які є необхідними та достатніми для запобігання, виявлення і протидії корупції у своїй діяльності.

Внутрішні нормативні документи «Ідея банку» передбачають усі можливі заходи протидії корупції та запобігання фрінансовим зловживанням. 3 метою запобігання та протидії корупції та хабарництву планується розробка та запровадження антикорупційної програми, яка буде обов'язковою для дотримання працівниками всіх рівнів управління.

Далі нами було досліджено Звіти про управління 5 українських банків 3 приватним капіталом, зокрема це - ПУМБ, АТ «Мегабанк», АТ «Таскомбанк», АТ «Полікомбанк», АТ «Альтбанк» (рис. 3).
За результатами 2019 року всі банки, окрім «Мегабанку» отримали прибуток. Значний збиток останнього пояснюється проведенням відрахування до резерву під кредитні збитки. Лідером за розміром отриманого прибутку у 2018-2019 рр. $\epsilon$ «ПУМБ», його значення збільшилось на 14\% порівняно з 2018 роком. Варто відзначити, що у 2019 році «ПУМБ» було визнано одним з найбільш надійних банків України. 3 огляду на це банк залишається і найбільш рентабельним, а саме: 1 витрачена гривня активів генерує 4,25 гривень прибутку. Даний показник нижчий у порівняні з банками державної власності та 3 іноземним капіталом, проте найкращий у своїй групі.

Окрему увагу ми приділили аналізу «Альтбанку», на кінець 2019 року чисті активи Банку становили 1359 млн. грн. - це на 99\% більше ніж у попередньому 2018 році. Головним чином значне збільшення обумовлено зростанням кредитного портореля та високоліквідних цінних паперів, при цьому загальна чисельність працівників станом на 31.12.2019 становила всього 75 осіб.

Питання запобігання корупційних схем не висвітлені у двох із проаналізованих банків «Полікомбанк» та «Альтбанк», їх відсутність у Звіті останнього банку пояснюється тим, що кількість штатних працівників менша, ніж 500 осіб, тобто один із критеріїв Інструкції № 373 не виконаний. У свою чергу «Полікомбанк», як в 2018, так і в 2019 році не розкриває інсрормацію щодо антикорупційної діяльності, хоча кількість працівників банку перевищує 500 осіб.

Антикорупційна програма «ПУМБ» розроблена відповідно до Конституції України,

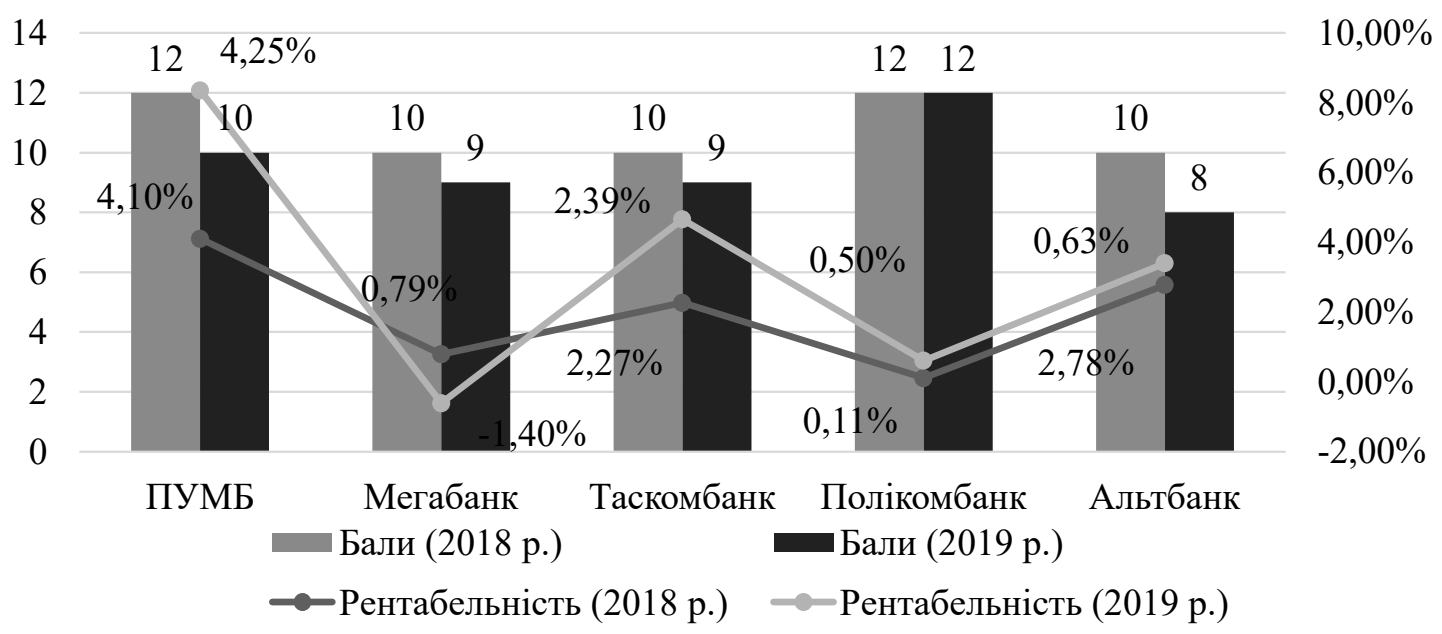

Рис. 3. Рентабельність активів банків з приватним капіталом у 2018-2019 рр., \% та бальна оцінка повноти розкриття інформації у Звіті про управління 
Закону України «Про протидію корупції» та іншого антикорупційного законодавства. У 2019 році банк реалізовував комплекс заходів, спрямованих на контроль дотримання вимог, управління ризиками, протидію легалізації коштів, отриманих злочинним шляхом, фрінансуванню тероризму та розповсюдженню зброї масового знищення. У «ПУМБ» впроваджені такі внутрішні процеси для забезпечення дотримання корпоративної етики та недопущення корупції: «лінія довіри», фрункція комплаєне, фрінансово-економічна безпека, система управління операційним ризиком. Крім того, в банку впроваджена політика нульової толерантності до шахрайства. Дана політика була висвітлена і в Звіті «Таскомбанку».

Пункт боротьби з корупцією у «Мегабанку» не відрізняється за змістом у порівнянні 3 2018 роком, та має більш ознайомчий характер. У Звіті вони наголошують, що основним джерелом корупції є органи та установи, які мають вплив на прийняття важливих громадських або господарських рішень (суди, міністерства, комітети та інші). Однак в зоні ризику знаходяться операції 3 кредитування та затвердження різного роду тарифрів на обслу- говування клієнтів. 3 огляду на це банком розроблено ряд внутрішньобанківських нормативних документів (Положення про Кредитний комітет АТ «Мегабанк», Положення про Тарифний комітет АТ «Мегабанк», інше), які регламентують порядок узгодження щодо надання кредитів та встановлення та узгодження тарифрів на обслуговування та практично зводять до мінімуму ризики, пов'язані 3 недобросовісним виконанням своїх службових обов'язків керівниками та співробітниками банку.

Для того, щоб виявити взаємозв'язок між прозорістю діяльності банку та його результатами діяльності згрупуємо отримані результати (табл. 1).

Таким чином, найбільш успішними з огляду на рентабельність виявились банки іноземних банківських груп - в середньому 5,4-5,5\%. Найнижчі показники у банків 3 приватним капіталом. Оцінка структури Звіту дає змогу нам зробити висновок про прямий зв'язок між рівнем транспарентності банку та його фрінансовою успішністю. У свою чергу варто відзначити, що високий рівень прозорості впливає на прибутковість 3 лагом в 1 рік, тобто висока

Таблиця 1

Аналіз прибутку та рентабельності 15 українських банків трьох груп у 2018-2019 рр.

\begin{tabular}{|c|c|c|c|c|c|c|}
\hline \multirow{2}{*}{ Назва банку } & \multicolumn{2}{|c|}{$\begin{array}{c}\text { Прибуток, } \\
\text { млн. грн. }\end{array}$} & \multicolumn{2}{|c|}{$\begin{array}{c}\text { Рентабельність } \\
\text { активів, \% }\end{array}$} & \multicolumn{2}{|c|}{$\begin{array}{c}\text { Оцінка структури } \\
\text { Звіту }\end{array}$} \\
\hline & 2018 & 2019 & 2018 & 2019 & 2018 & 2019 \\
\hline \multicolumn{7}{|c|}{ I група - банки державної власності } \\
\hline Ощадбанк & 162 & 255 & $0,07 \%$ & $0,10 \%$ & 14 & 14 \\
\hline Приватбанк & 12789 & 32609 & $4,60 \%$ & $10,53 \%$ & 10 & 10 \\
\hline Укрексімбанк & 852 & 64 & $0,53 \%$ & $0,05 \%$ & 10 & 12 \\
\hline Укргазбанк & 769 & 1288 & $0,94 \%$ & $1,08 \%$ & 10 & 11 \\
\hline "Розрах-й центр" & 36 & 15 & $11,80 \%$ & $3,93 \%$ & 9 & 11 \\
\hline Середнє значення: & 2921,6 & 6846,2 & $3,59 \%$ & $3,14 \%$ & 10,60 & 11,60 \\
\hline \multicolumn{7}{|c|}{ II група - банки іноземних банківських груп } \\
\hline Райфрфайзен банк & 5235 & 4834 & $7,09 \%$ & $5,83 \%$ & 12 & 13 \\
\hline АЛЬФА-БАНК & 1310 & 1925 & $2,16 \%$ & $2,68 \%$ & 10 & 10 \\
\hline ОТП банк & 1974 & 2537 & $6,03 \%$ & $5,67 \%$ & 13 & 14 \\
\hline УкрСиббанк & 2615 & 2789 & $4,92 \%$ & $5,36 \%$ & 9 & 10 \\
\hline Ідея банк & 378 & 336 & $6,99 \%$ & $7,99 \%$ & 10 & 10 \\
\hline Середнє значення: & 2302,4 & 2484,2 & $5,44 \%$ & $5,50 \%$ & 10,80 & 11,40 \\
\hline \multicolumn{7}{|c|}{ III група - банки з приватним капіталом } \\
\hline ПУМБ & 2100 & 2393 & $4,10 \%$ & $4,25 \%$ & 12 & 10 \\
\hline Мегабанк & 77 & -130 & $0,79 \%$ & $-1,40 \%$ & 10 & 9 \\
\hline Таскомбанк & 402 & 459 & $2,27 \%$ & $2,39 \%$ & 10 & 9 \\
\hline Полікомбанк & 0,7 & 3,3 & $0,11 \%$ & $0,50 \%$ & 12 & 13 \\
\hline Альтбанк & 19 & 8,5 & $2,78 \%$ & $0,63 \%$ & 10 & 8 \\
\hline Середнє значення: & 519,74 & 546,76 & $2,01 \%$ & $1,27 \%$ & 10,80 & 9,80 \\
\hline
\end{tabular}


оцінку Звіту у 2019 році повинна сприяти підвищенню рівня рентабельності у 2020 році.

Висновки і пропозиції. Дослідження Звітів про управліннях всіх представлених 15 банків дає змогу зробити висновок про те, що банки державної власності та банки іноземних банківських груп більш повно дотримуються вимог Інструкції № 373, однак лише декілька банків детально висвітлюють усі 5 складових Звіту про управління, а саме: АТ Ощадбанк, АТ «Райфрфайзен банк Аваль» та «АЛЬФАБАНК». У свою чергу банки 3 приватним капіталом, окрім «ПУМБ», другий рік поспіль складають Звіт про управління формального характеру, не висвітлюючи важливі ключові індикатори.

3 огляду на гостру актуальність проблеми детінізації економіки ми велику увагу приділяли пунктам, які відображають антикорупційні заходи та механізми запобігання шахрайства. Порівняння інорормації поданої у Звітах у 2018 та 2019 роках дало нам змогу зробити висновок, що переважна більшість банків у своїй діяльності керується загальною антикорупційною програмою не вживаючи жодних додаткових заходів для забезпечення прозорості. Декілька банків зовсім не деталізують даний аспект. Єдиний банк, який звітує про конкретні результати діяльності щодо запобіганню шахрайству - це «Приватбанк».

У свою чергу складання Звіту про управління $€$ великим кроком на зустріч прозорості банківського сектору. Банки 3 державною часткою повинні стати прикладом того, наскільки відкритою та доступною має бути діяльність фрінансової установи. Звітність банки іноземних банківських груп з огляду на форму власності мають максимально відповідати вимогам МСФ3, які у свою чергу велику увагу приділяють повноті розкриття інфрормації. Гіпотеза про те, що більш транспаранті банки є більш фрінансово успішними та прибутковими підтвердилась частково і потребує подальших досліджень.

\section{СПИСОК ВИКОРИСТАНИХ ДЖЕРЕЛ:}

1. Про бухгалтерський облік та фрінансову звітність в Україні : Закон України від 16.07.1999 р. № 996. URL: https://zakon.rada.gov.ua/laws/show/996-14

2. Міжнародні стандарти контролю якості, аудиту, огляду, іншого надання впевненості та супутніх послуг. ч. 1 / Переклад з англ. О. Л. Ольховікова [та ін.]. Київ : Міжнародна федерація бухгалтерів; Аудиторська палата України, 2010. 846 c.

3. Про затвердження Порядку подання фінансової звітності : постанова Кабінету Міністрів України від 28.02.2000 р. № 419. URL: https://zakon.rada.gov.ua/laws/show/419-2000-\%D0\%BF\#Text

4. Методичні рекомендації зі складання звіту про управління : рекомендації, затверджені наказом Мінфіну України від 07.12.2018 р. № 982. URL: https://zakon.rada.gov.ua/rada/show/v0982201-18

5. Про порядок складання та оприлюднення фрінансової звітності банків України : інструкція, затверджена постановою Правління НБУ від 24.11.2011 р. № 373. URL: http://zakon2.rada.gov.ua/laws/show/z1288-11

6. Безверхий К. В., Пантелєєв В. П. Консолідований звіт про управління. Новації управлінської практики звітування. Науковий вісник Національної академії статистики, обліку та аудиту. 2018. № 1-2. С. 37-46.

7. Новіченко Л. С. Актуальні питання формування Звіту про управління підприємством. Економічний аналіз. Тернопіль, 2018. Том 28. № 4. С. 258-264.

8. Царук Н. Г. Підготовка звіту про управління - новий виклик для бухгалтера. Бізнес-навігатор. 2019. Вип. 3-2. С. 120-125.

9. Сучасні тенденції обліку, аналізу й оподаткування в умовах євроінтеграції : монографрія / за заг. ред. Т. Г. Савченко, І. М. Бурденко. Суми : Сумський державний університет, 2020. 147 с.

\section{REFERENCES:}

1. Pro bukhhalterskyi oblik ta finansovu zvitnist v Ukraini: Zakon Ukrainy vid 16.07.1999 r. № 996. Retrieved from: https://zakon.rada.gov.ua/laws/show/996-14

2. Mizhnarodni standarty kontroliu yakosti, audytu, ohliadu, inshoho nadannia vpevnenosti ta suputnikh posluh. Ch. 1 / Pereklad z anhl. O. L. Olkhovikova [ta in.]. Kyiv: Mizhnarodna federatsiia bukhhalteriv; Audytorska palata Ukrainy, 2010. 846 p. (in Ukrainian)

3. Pro zatverdzhennia Poriadku podannia finansovoi zvitnosti: postanova Kabinetu Ministriv Ukrainy vid 28.02.2000 r. № 419. Retrieved from: https://zakon.rada.gov.ua/laws/show/419-2000-\%D0\%BF\#Text

4. Metodychni rekomendatsii zi skladannia zvitu pro upravlinnia: rekomendatsii, zatverdzheni nakazom Minfinu Ukrainy vid 07.12.2018 r. № 982. Retrieved from: https://zakon.rada.gov.ua/rada/show/v0982201-18 
5. Pro poriadok skladannia ta opryliudnennia finansovoi zvitnosti bankiv Ukrainy: instruktsiia, zatverdzhena postanovoiu Pravlinnia NBU vid 24.11.2011 r. № 373. Retrieved from: http://zakon2.rada.gov.ua/laws/show/z1288-11

6. Bezverkhyi K. V., Panteleev V. P. (2018). Consolidated Management Report. Innovations in Managerial Reporting Practices. Scientific Bulletin of the National Academy of Statistics, Accounting and Audit, 1-2, 37-46. (in Ukrainian)

7. Novichenko L. S. (2018). Aktulni pytannia formuvannia Zvitu pro upravlinnia pidpryiemstvom. Ekonomichnyi analiz. Ternopil, Tom 28, no. 4, pp, 258-264. (in Ukrainian)

8. Tsaruk N. H. (2019). Pidhotovka zvitu pro upravlinnia - novyi vyklyk dlia bukhhaltera. Biznes-navihator, vol. 3-2, pp. 120-125. (in Ukrainian)

9. Suchasni tendentsii obliku, analizu y opodatkuvannia v umovakh yevrointehratsii: monohrafiia (2020) I za zah. red. T. H. Savchenko, I. M. Burdenko. Sumy: Sumskyi derzhavnyi universytet, 147 p. 